\title{
Genetic Changes in Seasonal Generations of the Bank Vole
}

\author{
Anna FEDYK \& Marek GĘBCZYŃSKI
}

\begin{abstract}
Fedyk A. \& Gębczyński M., 1980: Genetic changes in seasonal generations of the bank vole. Acta theriol., 25, 39: 475-485 [With 5 Tables].

Examination was made of 17 different proteins coded by 36 loci (33 loci in spring) in the bank vole Clethrionomys glareolus (Schreber, 1780) caught in April-May (spring generation) and in SeptemberOctober (autumn generation). The autumn population consisted of resident and migrating individuals, while only resident voles were caught in spring. It was therefore possible to make comparisons of allele frequency, genotypic fixation indexes and heterozygosity $(\bar{H})$ between these three groups of voles and to calculate genetic similarity. Thus $\bar{H}$ of resident individuals in autumn is 0.032 and migrants 0.035 , while in spring this value is 0.042 in residents. The genetic similarity coefficients for migrants and residents were $0.970(I)$, and $0.970(S)$ : and when resident individuals from spring and autumn are compared the figures are $0.946(I)$ and $0.940(S)$. Allele frequency in some of the loci examined fluctuates greatly in different groups of bank voles, the difference being greatest between residents in spring and autumn. Generally speaking it may be said that the differences obtained are more distinct between seasons than between resident and migrant individuals from the same season.

[Mammals Res. Inst., Polish Acad. Sci., 17-230 Białowieża, Poland].
\end{abstract}

\section{INTRODUCTION}

In order to obtain a fuller understanding of many ecological processes it is essential to examine genetic variability and genetic differentiation in the population. Using the genus Microtus as an example it has been shown that frequency of genes fluctuates depending on population density ( $\mathrm{T}$ a m a rin \& $\mathrm{Kr}$ ebs, 1969; Gaines \& $\mathrm{Krebs}$, 1971; K rebs et al., 1976). Spatial and temporal changes are also reflected in the gene pool of the rodents (S mith et al., 1978) and ungulates (S mith et al., 1980).

The bank vole, Clethrionomys glareolus (Schreber, 1780) is a rodent distinguished not only by its wide geographical range, but also by distinct variations in numbers of the $4-5$ year cycle, and also by seasonal variation (see data collected by $\mathrm{French}$ et al., 1975). In the Białowieża National Park estimates of numbers made over a period of [475] 
30 years have confirmed that there is a complex recurring cycle in the population of the bank vole ( $\mathrm{Pucek} \& \mathrm{Puc}$ e k, in litt.).

The purpose of the present study was to describe biochemical variations in bank voles caught in spring (spring generation) and autumn (autumn generation). The bank voles of these generations differ in respect of a large number of physiological and ecological characteristics ( $\mathrm{F} \mathrm{e} \mathrm{d} \mathrm{y} \mathrm{k,} \mathrm{1974).} \mathrm{As} \mathrm{some} \mathrm{of} \mathrm{the} \mathrm{individuals} \mathrm{migrate} \mathrm{in} \mathrm{autumn,} \mathrm{most}$ probably on account of their great density, this group could be compared with the resident group. Attempts were therefore made at determining not only seasonal differences, but also those due to degree of their resident character, which primarily reflects age differences. When the habitat is saturated, the individuals migrating usually belong to the youngest age classes (Andrzejewski, 1969; Lidicker, 1975).

\section{MATERIAL}

The object of this study was formed by a population of bank voles living in the Tilio-Carpinetum forest (sector 283) of the Białowieża National Park. The bank voles were caught in live-traps distributed in pairs on all the stations, each of which was situated at $20 \mathrm{~m}$ intervals, forming 12 lines with 12 trapping stations in each. A total of 288 live-traps distributed over an area of 5.76 ha were in operation. After the traps had been placed in position, each containing oats, they were left open for $2-3$ days to attract the rodents. On the following day the traps were put into operation and the voles caught during the following three days were marked by cutting off the brown-tinted ends of the fur on their backs. Trapping was next carried out for $10-15$ days and all the previously marked individuals (= residents) and unmarked (= migrants) were removed, taken to the laboratory and killed as the electrophoretic analyses proceeded.

\section{METHODS}

Variation in proteins was examined by the electrophoresis method on starch gel, in the horizontal arrangement. General principles for procedure were followed after Selander et al., (1971). Starch hydrolyzed spontaneously. Starch gel of $13 \%$ concentration was used for separations.

\section{RESULTS}

\subsection{Monomorphic Proteins}

About half of the loci examined do not exhibit polymorphism, and jointly 17 monomorphic loci were found. In several cases a rapid or slow band shown to be present and these loci were held to be monomorphic and were not taken into account when calculating genetic differentiation (Table 1). 
Table 1

Electrophoretic variation in proteins of the bank vole.

\begin{tabular}{|c|c|c|c|}
\hline Protein and locus & Tissue & $\begin{array}{l}\text { Phenotypic } \\
\text { variation }\end{array}$ & $\begin{array}{l}\text { Number } \\
\text { of alleles }\end{array}$ \\
\hline \multicolumn{4}{|l|}{ Esterases } \\
\hline Es-1 & erythrocytes & polymorphic & 2 \\
\hline Es-2 & erythrocytes & monomorphic & 1 \\
\hline Es-3 & erythrocytes & polymorphic & 2 \\
\hline$E s-4$ & plasma & monomorphic & 1 \\
\hline$E s-5$ & plasma & polymorphic & 2 \\
\hline Es-6 & plasma & monomorphic & 1 \\
\hline Es-7 & plasma & polymorphic & 3 \\
\hline Es-8 & liver & polymorphic & 2 \\
\hline Es-9 & liver & polymorphic & 2 \\
\hline$E s-10$ & liver & polymorphic & 2 \\
\hline Es-11 & liver & monomorphic & 1 \\
\hline Es -12 & liver & monomorphic & 1 \\
\hline$E s-13$ & liver & polymorphic & 2 \\
\hline \multicolumn{4}{|l|}{ Lactate dehydrogenases } \\
\hline $\begin{array}{l}L d h-1 \\
L d h-2\end{array}$ & kidney & polymorphic & 2 \\
\hline Malate dehydrogenases & kidney & polymorphic & 2 \\
\hline$M d h-1$ & kidney & polymorphic & \\
\hline$M d h-2$ & kidney & monomorphic & 1 \\
\hline \multicolumn{4}{|l|}{ Malic enzyme } \\
\hline \multicolumn{4}{|l|}{$\begin{array}{l}\text { Me } \\
\text { Xanthine dehydrogenases }\end{array}$} \\
\hline Xdh-1 & liver & monomorphic & 1 \\
\hline$X d h-2$ & liver & monomorphic & 1 \\
\hline Alcohol dehydrogenase, Adh & liver & monomorphic & $2^{1}$ \\
\hline \multicolumn{4}{|l|}{ Sorbitol dehydrogenases } \\
\hline $\begin{array}{l}\text { Sordh-1 } \\
\text { Sordh-2 }\end{array}$ & $\begin{array}{l}\text { liver } \\
\text { liver }\end{array}$ & $\begin{array}{l}\text { monomorphic } \\
\text { monomorphic }\end{array}$ & $\begin{array}{l}1 \\
2_{1}\end{array}$ \\
\hline Sordh-3 & liver & monomorphic & $\begin{array}{l}2^{*} \\
1\end{array}$ \\
\hline Glucose dehydrogenase, Gdh & liver & polymorphic & 2 \\
\hline \multicolumn{4}{|l|}{ Phosphogluconate dehydrogenase, } \\
\hline \multicolumn{4}{|l|}{$\begin{array}{l}\text { Pgd } \\
\alpha \text {-glycerophosphate dehydrogenases }\end{array}$} \\
\hline $\begin{array}{l}\alpha-G p d h-1 \\
\alpha-G p d h-2\end{array}$ & liver & polymorphic & 2 \\
\hline $\begin{array}{c}\alpha-G p d h-2 \\
\text { Catalase, Cat. }\end{array}$ & liver & monomorphic & 1 \\
\hline Catalase, Cat. & $\begin{array}{l}\text { plasma or } \\
\text { liver }\end{array}$ & monomorphic & 1 \\
\hline \multirow{2}{*}{\multicolumn{4}{|c|}{$\begin{array}{l}\text { Superoxidase dismutase (tetrazolium } \\
\text { oxidase), Sod }\end{array}$}} \\
\hline & liver & monomorphic & 1 \\
\hline $\begin{array}{l}\text { Adenylate kinase, } A k \\
\text { Nonenzymatic proteins }\end{array}$ & liver & pilymorphic & 3 \\
\hline $\begin{array}{l}\text { Nonenzymatic proteins } \\
\text { Hemoglobin, } \mathrm{Hg}\end{array}$ & exythrocytes & monomorphic & \\
\hline Transferrin, $T f$ & plasma & monomorphic & 21 \\
\hline Albumin, Alb. & plasma & polymorphic & 2 \\
\hline Protein B, Prot. B & muscle & polymorphic & 2 \\
\hline
\end{tabular}

${ }^{1}$ As the single specimens with a slow (or fast) band were observed they were not included into calculations of heterozygosity.

Es-2 (erythrocytes). The most anodally migrating erythrocytic esterase is uniformly monomorphic in all samples. 
Es-4 (plasma). The most anodally migrating esterase in the plasma is monomorphic.

Es-6 (plasma). This esterase migrates with moderate rapidity and is monomorphic in all samples.

Es-11 and Es-12 (liver). These are two esterasés migrating only a short distance and are monomorphic. A rapid band was observed in one bank vole only (autumn, M).

$M d h-2$ (kidney). This form of NAD-dependent malate dehydrogenase is monomorphic.

Xanthine, alcohol and sorbitol dehydrogenases of liver are monomorphic. In occasional cases, however, Adh and Sordh-2 loci exhibited a different migration rate from that of all the other individuals. Alphaglycerophosphate dehydrogenase- 2 of liver is also monomorphic. Of the other enzymes, catalase of plasma and liver and superoxidase dismutase show no polymorphism in any sample. Hemoglobin (erythrocytes) and transferrin (plasma), however, have been given as monomorphic, since only in occasional cases was a different migration rate found from that shown for all the other samples.

\subsection{Polymorphic Loci}

Allele Frequency

Allele frequency in 16 (spring) or 19 (autumn) polymorphic loci depends not only on the given locus, but also on the group of bank voles examined (Table 2). When allele frequency was compared in the group of resident bank voles in spring and autumn it was found that the greatest differences were those in respect of Es-7 and $M e$ loci. Far lesser differences apply to Pgd, Es-13, Mdh-1, Lap and Gdh loci, while the allele frequency in resident voles from the two seasons is practically identical in the following loci: Es-8, Ldh-1, Ldh-2, Alb. and Prot. B. In autumn migrating voles exhibit, in comparison with spring residents, the greatest differences in allele frequency of such loci as: $G d h, L d h-2$, $M e$ and $\alpha-G p d h-1$. The smallest differences apply to $E s-13, M d h-1$, Prot. B, Ldh-1 and Es-8. Both groups of voles caught in autumn (residents and migrants) differ primarily in respect of frequency in the following loci: $E s-7, L d h-2$ and $E s-13$, and negligible differences apply to $E s-1, E s-3, E s-8, L d h-1$, Prot.B and Es-9. The remaining loci exhibit an intermediate degree of difference in allele frequency.

Heterozygosity and Genic Similarity

Heterozygosity calculated per locus per group of the bank vole is relatively low and comes between 0.010 and 0.062 (Table 3). Locus $A k$ 
exhibited maximum heterozygosity in all groups. In spring $\bar{H}$ higher than 0.05 is characteristic of the following loci also: $E s-9, L d h-1, L d h-2$, $M d h-1$, Lap and Prot.B. In autumn, in the case of resident voles, only locus $M e$, in addition to locus $A k$, exceeds this index. In migrating voles in autumn, however, locus $A k$ is 0.046 and loci $L d h-1$ and $\alpha-G p d h-1$ have the greatest heterozygosity. The three groups of voles examined

Table 2

Allele frequencies at $16 / 19$ polymorphic loci of different bank voles groups. $\mathrm{R}$ - residents; $\mathrm{M}$ - migrants.

\begin{tabular}{|c|c|c|c|c|}
\hline Locus & Alleles & $\begin{array}{c}\text { Spring } \\
\mathrm{R} ; \mathrm{n}=35\end{array}$ & $\begin{array}{l}\text { Autumn } \\
\mathrm{R} ; \mathrm{n}=31\end{array}$ & $\begin{array}{l}\text { Autumn } \\
M ; n=54\end{array}$ \\
\hline \multirow[t]{2}{*}{ Es-1. } & a & - & 0.56 & 0.53 \\
\hline & b & - & 0.44 & 0.47 \\
\hline \multirow[t]{2}{*}{ Es-3 } & a & - & 0.77 & 0.74 \\
\hline & b & - & 0.23 & 0.26 \\
\hline \multirow[t]{2}{*}{$E s-5$} & a & - & 0.37 & 0.43 \\
\hline & b & - & 0.63 & 0.57 \\
\hline \multirow{3}{*}{ Es-7 } & a & 0.03 & 0.19 & 0.06 \\
\hline & b & 0.36 & 0.73 & 0.47 \\
\hline & c & 0.61 & 0.08 & 0.46 \\
\hline \multirow[t]{2}{*}{ Es-8 } & a & 0.71 & 0.74 & 0.71 \\
\hline & b & 0.29 & 0.26 & 0.29 \\
\hline \multirow{2}{*}{ Es-9 } & a & 0.50 & 0.44 & 0.44 \\
\hline & b & 0.50 & 0.56 & 0.56 \\
\hline \multirow[t]{2}{*}{ Es-10 } & a & 0.59 & 0.48 & 0.63 \\
\hline & b & 0.41 & 0.52 & 0.37 \\
\hline \multirow[t]{2}{*}{$E s-13$} & a & 0.79 & 0.61 & 0.77 \\
\hline & b & 0.21 & 0.39 & 0.23 \\
\hline \multirow[t]{2}{*}{$L d h-1$} & a & 0.50 & 0.48 & 0.51 \\
\hline & $\mathrm{b}$ & 0.50 & 0.52 & 0.49 \\
\hline \multirow[t]{2}{*}{$L d h-2$} & a & 0.49 & 0.48 & 0.76 \\
\hline & b & 0.51 & 0.52 & 0.24 \\
\hline \multirow[t]{2}{*}{$M d h-1$} & a & 0.50 & 0,34 & 0.48 \\
\hline & b & 0.50 & 0.66 & 0.52 \\
\hline \multirow[t]{2}{*}{ Me } & a & 0.23 & 0.50 & 0.46 \\
\hline & b & 0.77 & 0.50 & 0.54 \\
\hline \multirow[t]{2}{*}{ Gdh } & a & 0.36 & 0.50 & 0.64 \\
\hline & b & 0.64 & 0.50 & 0.46 \\
\hline \multirow[t]{2}{*}{ Pgd } & a & 0.60 & 0.79 & 0.64 \\
\hline & b & 0.40 & 0.21 & 0.36 \\
\hline \multirow[t]{2}{*}{$\alpha-G p d h-1$} & a & 0.36 & 0.47 & 0.53 \\
\hline & b & 0.64 & 0.53 & 0.47 \\
\hline \multirow[t]{2}{*}{ Lap } & a & 0.53 & 0.68 & 0.63 \\
\hline & $\mathrm{b}$ & 0.47 & 0.32 & 0.37 \\
\hline \multirow[t]{2}{*}{ Prot. B } & a & 0.50 & 0.50 & 0.52 \\
\hline & b & 0.50 & 0.50 & 0.48 \\
\hline \multirow[t]{2}{*}{ Alb. } & a & 0.49 & 0.48 & 0.38 \\
\hline & b & 0.51 & 0.52 & 0.62 \\
\hline \multirow[t]{3}{*}{$A k$} & a & 0.34 & 0.29 & 0.34 \\
\hline & b & 0.41 & 0.39 & 0.35 \\
\hline & c & 0.25 & 0.32 & 0.31 \\
\hline
\end{tabular}


have the greatest heterozygosity. The three group of voles examined thus differ slightly in respect of degree of heterozygosity. The average value for all the loci examined is greatest for voles in spring (residents), and lowest for residents in autumn, although the group of autumn migrants differs from residents from the same season to a negligible degree only (Table 3).

Table 3

Mean heterozygosity per locus per group of the bank voles.

\begin{tabular}{|c|c|c|c|c|}
\hline \multirow{2}{*}{ Locus } & \multirow{2}{*}{$\begin{array}{l}\text { Spring } \\
\text { Resident }\end{array}$} & \multicolumn{2}{|c|}{ Autumn } & \multirow{2}{*}{ Mean } \\
\hline & & Resident & Migrant & \\
\hline Es-1 & - & 0.046 & 0.046 & 0.046 \\
\hline Es-3 & - & 0.020 & 0.025 & 0.023 \\
\hline Es-5 & - & 0.039 & 0.035 & 0.037 \\
\hline Es-7 & 0.023 & 0.012 & 0.024 & 0.020 \\
\hline Es-8 & 0.032 & 0.024 & 0.019 & 0.025 \\
\hline Es-9 & 0.059 & 0.025 & 0.042 & 0.042 \\
\hline Es-10 & 0.023 & 0.034 & 0.035 & 0.031 \\
\hline Es-13 & 0.012 & 0.037 & 0.015 & 0.021 \\
\hline$L d h-1$ & 0.059 & 0.037 & 0.052 & 0.049 \\
\hline$L d h-2$ & 0.057 & 0.037 & 0.021 & 0.038 \\
\hline$M d h-1$ & 0.052 & 0.032 & 0.049 & 0.044 \\
\hline $\mathrm{Me}$ & 0.029 & 0.053 & 0.049 & 0.044 \\
\hline Gdh & 0.023 & 0.036 & 0.041 & 0.033 \\
\hline Pgd & 0.043 & 0.012 & 0.030 & 0.028 \\
\hline$\alpha-G p d h-1$ & 0.038 & 0.049 & 0.050 & 0.046 \\
\hline Lap & 0.052 & 0.020 & 0.025 & 0.032 \\
\hline Prot. B & 0.059 & 0.042 & 0.043 & 0.048 \\
\hline Alb. & 0.043 & 0.010 & 0.025 & 0.026 \\
\hline$A k$ & 0.062 & 0.051 & 0.046 & 0.053 \\
\hline Mean & 0.042 & 0.032 & 0.035 & 0.036 \\
\hline
\end{tabular}

Calculation was also made of deviations from the Hardy-Weinberg equilibrium and measure of heterozygote deficiency (Table 4). This made it possible to establish that in spring 9 of the 16 loci exhibit deviation from the random distribution and that in all these cases an excess of heterozygotes is observed. In autumn also 11 out of 19 polymorphic loci, in both resident and migrant voles, exhibit deviation from the HardyWeinberg equilibrium. In migrating voles all these loci have a negative $F_{i}$ value, which points to the predominance of heterozygotes over homozygotes. Only in two cases, in residents in autumn, were loci Es-7 and $A l b$. found to indicate an excess of homozygotes, while all the other loci point to their deficiency (Table 4). Neither locus exhibiting an excess of homozygotes in resident voles in autumn showed deviation from the random distribution in migrants of the same season. Mean $F_{i}$ values for the study groups of bank voles are similar and come between -0.30 and -0.38 (Table 4 ).

Coefficients of genetic similarity were calculated for paired combina- 
tions of all groups (Table 5), using two measures of genetic similarity,indexes $I$ (N e i, 1972) and $S$ (Rogers, 1972). These two measures: arrange the groups of voles in the same order, within a range of 0.94 to 0.97 . In two cases coefficient $I$ is slightly greater than $S$. The two

Table 4

The genotypic fixation indexes (W right, 1965) and deviations from Hardy-Weinberg equilibrium. A critical value of $\chi^{2}$ is 3.841 at $P<0.05$. $F_{i}=1-H_{i}$ observed $/ \mathrm{H}_{\mathrm{i}}$ expected, where $\mathrm{H}_{\mathrm{i}}$ - proportion of heterozygotes

\begin{tabular}{|c|c|c|c|c|c|c|}
\hline \multirow[t]{2}{*}{ Locus } & \multicolumn{2}{|c|}{ Spring, R } & \multicolumn{2}{|c|}{ Autumn, R } & \multicolumn{2}{|c|}{ Autumn, M } \\
\hline & & $\chi^{2}$ & & & & \\
\hline Es-1 & - & - & -0.76 & 18.36 & -0.74 & 25.26 \\
\hline$E s-3$ & - & - & -0.09 & 0.32 & -0.24 & 3.39 \\
\hline Es-5 & - & - & -0.59 & 8.72 & -0.35 & 7.09 \\
\hline Es-7 & 0.18 & 3.15 & +0.47 & 5.75 & 0.05 & 2.78 \\
\hline$E s-8$ & -0.20 & 2.30 & -0.16 & 1.43 & 0.10 & 3.31 \\
\hline$E s-9$ & -0.88 & 27.45 & 0.02 & 0.01 & -0.61 & 20.65 \\
\hline Es-10 & 0.23 & 1.94 & -0.29 & 2.64 & -0.50 & 11.34 \\
\hline Es-13 & 0.12 & 3.71 & -0.48 & 7.47 & 0.09 & 2.52 \\
\hline$L d h-1$ & -0.88 & 27.45 & -0.41 & 5.49 & -0.90 & 50.14 \\
\hline$L d h-2$ & -0.82 & 24.09 & -0.41 & 5.49 & 0.11 & 0.70 \\
\hline$M d h-1$ & -0.64 & 15.11 & -0.25 & 3.62 & -0.85 & 39.44 \\
\hline Me & -0.09 & 3.08 & -1.00 & 31.00 & -0.85 & 40.20 \\
\hline Gdh & +0.23 & 1.27 & -0.31 & 3.70 & -0.56 & 17.21 \\
\hline Pgd & -0.29 & 6.42 & 0.29 & 3.01 & -0.17 & 3.22 \\
\hline$a-G p d h-1$ & -0.30 & 3.18 & -0.87 & 23.90 & -0.91 & 45.69 \\
\hline Lap & -0.66 & 15.37 & 0.11 & 2.45 & -0.02 & 0.05 \\
\hline Prot. B & -0.88 & 27.45 & -0.61 & 11.64 & -0.62 & 21.57 \\
\hline Alb. & -0.37 & 4.85 & 0.39 & 9.64 & 0.06 & 0.20 \\
\hline$A k$ & -0.75 & 13.84 & -0.81 & 11.97 & -0.33 & 11.36 \\
\hline Mean & -0.35 & & -0.30 & & -0.38 & \\
\hline
\end{tabular}

Table 5

Coefficients of genetic similarity ( $I$ and $S$ ) between groups of C. glareolus.

Upper figure, I (Nei's genic similarity); lower figure, $S$ (Rogers' genic similarity).

\begin{tabular}{cccc}
\hline Group & Spring, R & Autumn, R & Autumn, M \\
\hline Spring, R & 1.000 & 0.946 & 0.969 \\
& & 0.940 & 0.945 \\
Autumn, R & & 1.000 & 0.970 \\
Autumn, M & & & 0.970 \\
& & & 1.000
\end{tabular}

coefficients are identical in migrants and residents in autumn. They are highest between these groups, which points to considerable geneticsimilarity. The genetic distance is thus greater between voles from different seasons, in comparison with migrating and resident voles from: the same season. 


\section{DISCUSSION}

The frequency of genes $T f$ and Lap fluctuates, depending on population density in Microtus ochrogaster, M. pennsylvanicus and M. townsendii ( $\mathrm{T}$ a marin \& $\mathrm{Krebs}, 1969 ; \mathrm{G}$ a ines \& $\mathrm{Krebs}, 1971$; $\mathrm{Krebs}$ et al., 1976). Since seasonal changes in numbers cause, in a large number of rodent species, increase in population density from spring towards autumn (Andrzejewski, 1969), it was to be expected that this would be reflected in genic frequency in the bank vole also. In our case it can be said that at the end of September and beginning of October density was more than twice greater (85 individuals caught) than at the end of April and beginning of May (35 individuals caught). Some of the loci (cf. Table 2) were highly variable both when compared in migrating and resident individuals, and most particularly when comparisons were made between seasons. This considerable shift in allele frequency in several loci over so short a period of time provides confirmation of the earlier observations made on rodents ( $\mathrm{S} \mathrm{m}$ ith et al., 1978), and on wild and domesticated pigs (S m it h et al., 1980).

The difference found in autumn between migrants, that is, chiefly young voles, and resident voles, shows that selective pressure acts differently on these two groups of rodents. This phenomenon has been observed in other species also, e.g., Microtus (M y e r s \& K r e b s, 1971), although Blackwell \& Ramsey (1972) did not find a relation in Peromyscus between exploratory activity and changes in the genotype. The explanation for this difference may lie not only in the number of loci examined being too small, as assumed by Blackwell \& $\mathrm{R} \mathrm{a} \mathrm{m}$ s e y (1972). The essence of this matter lies primarily in the reasons for migration not being identical. Two types of migration can be distinguished: pre-satural, which does not, in Li dicker's opinion (1975), differentiate the population, and satural, characteristic of the enforced migration of younger and weaker individuals. Only this second type of migration can, therefore, be reflected in the gene pool through selective action of intrapopulation competition.

In spring all the individuals caught belonged to the resident group and their age differences were undoubtedly smaller during this period than in the autumn, as may be gathered from data for other bank vole populations (Andrzejewski, 1969). This does not alter the fact that it is in spring that the level of heterozygosity is highest. This would appear to provide unequivocal confirmation of the fact that in winter selection is directed in a different way from that during the spring and summer period, although in both cases only heterozygotes are in principle eliminated. It has been suggested earlier on (B e r r y, 1970) 
that different genotypes have different adaptability values in successive seasons of the year.

Data for genotypic fixation indexes form evidence of how strict such selection is. They show beyond doubt that in bank voles elimination includes homozygotes, this applying to both seasonal comparisons and also comparisons of migrants and residents. Only 2 loci out of 31 revealed an excess of homozygotes with all comparisons of this kind.

Average heterozygosity in all the three study groups of bank voles is close to the value proper to the mammals so far examined, that is 0.036 (N e v o, 1978). In the bank vole, however, a species with a very wide geographical range, it might have been expected that the level of genetic variation would be higher, since this characterizes widespread mammal species ( $\mathrm{N} \mathrm{e} \mathrm{v} \mathrm{o,} \mathrm{1978).}$

Coefficients of overall genic similarity between the study groups of bank voles are high, but even so they come within values proper to many populations of the mammal species studied. For instance index $S$ for different populations is: in Sigmodon - 0.98 ( $\mathrm{J}$ ohns on et al., 1972), Thomomys bottae and T. umbrinus - 0.93 (P a t t o $\mathrm{n}$ et al., 1972), Mus musculus - 0.88 (Rog e rs, 1972), Peromyscus floridanus - 0.97 (S mith et al., 1973). As the genetic distance between seasonal generations of voles is greater than between migrants and residents in the autumn, it may be taken that in winter selection of homozygotes is stricter than in spring and summer. The value of average heterozygosity found in the spring generation also points to this.

Further studies carried out in different seasons in successive years will make it possible to discover the selective action on bank vole populations in different phases of the cycle of their numbers, and consequently will also permit of interpreting the relations between seasonal and long-term differences in population density.

Acknowledgements: Thanks are due to Dr. J. Rafiński for his generous help and critical comments on the manuscript.

\section{REFERENCES}

1. Andrzejewski R., 1969: Analysis in results of catches of small mammals by the Calendar of catches method. Zesz. nauk. Inst. Ekol., 2: 1-104 [In Polish with English summ.].

2. Berry R. J., 1970. Covert and overt variation, as exemplified by British mouse populations. Symp. zool. Soc. Lond., 26: 3-26.

3. Blackwell T. L. \& Ramsey P. R., 1972: Exploratory activity and lack of genotypic correlates in Peromyscus polionotus. J. Mamm., 53: 401-403.

4. Fedyk A., 1974: Gross body composition in postnatal development of the 
bank vole. II. Differentiation of seasonal generations. Acta theriol., 19: 403 $-427$.

5. French N. R., Stoddart D. M. \& Bobek B., 1975: Patterns of demography in small mammal populations. [In: "Small mammals: their productivity and population dynamics«, eds. F. B. Golley, K. Petrusewicz, L. Ryszkoski]. Cambridge Univ. Press: 73-102.

6. Gaines M. S. \& Krebs C. J., 1971: Genetic change in fluctuating vole populations. Evolution, 25: 702-723.

7. Johnson F. M., Schaeffer H. E., Gillespie J. F. \& Rockwood E. S., 1969: Isozyme genotype-environment relationship in natural populations of the harvester ant, Pogonomyrmex barbatus, from Texas. Biochem. Genet. 3: $429-450$.

8. Krebs C. J., Wingate J., Le Duc J., Redfield J. A., Taitt M. \& Hilborn T., 1976: Microtus population biology: dispersal in fluctuating populations of $M$. townsendii. Can. J. Zool., 54: 79-95.

9. Lidicker W. Z., Jr., 1975: The role of dispersal in the demography of small mammals. [In: "Small mammals: their productivity and population dynamics«, eds. F. B. Golley, K. Petrusewicz, L. Ryszkowski]. Cambridge Univ. Press: $103-128$.

10. M y e r s J. H. \& C. J., 1971: Genetic, behavioural, and reproductive attributes of dispersing field voles Microtus pennsylvanicus and Microtus ochrogaster. Ecol. Monogr., 41: 53-78.

11. N e i M., 1972: Genetic distance between populations. Am. Natur., 106: 283-292.

12. Nevo E., 1978: Genetic variation in natural populations: patterns and theory. Theor. Pop. Biol., 13: 121-177.

13. Nevo E., Kim Y. J., Shaw C. R., \& Thaeler C. S., Jr., 1974: Genetic variation, selection and speciation in Thomomys talpoides pocket gophers. Evolution, 28: 1-23.

14. Patton J. L., Selander R. K., \& S mith M. H., 1972: Genic variation in hybrydizing populations of gophers (genus Thomomys). Syst. Zool., 21: 263-270.

15. R o gers J. S., 1972: Measures of genetic similarity and genetic distance. Univ. Texas Publ., 7213: 145-153.

16. Selander R. K., Smith M. H., Yang S. Y., Johnson W. E. \& Gentry G. B., 1971: Biochemical polymorphism and systematics in the genus Peromyscus. I. Variation in the oldfield mouse (Peromyscus polionotus). Univ. Texas Publ., 7103: 49-90.

17. Smith M. H., Manlove M. N. \& Joule J., 1978: Spatial and temporal dynamics of the genetic organization of small mammal populations. [In: "Small mammal population dynamics«, ed. D. Snyder]. Spec. Publ. Ser. Pymatuning Lab. Ecol., 5: 99-113.

18. Smith M. H., Selander R. K. \& Johnson W. E., 1973: Biochemical polymorphism and systematics in the genus Peromyscus. III. Variation in the Florida deer mouse (Peromyscus floridanus), a Pleistocene relict. J. Mamm., 54: $1-13$.

19. Smith M. W., Smith M. H. \& Bris bin I. L., Jr., 1980: Genetic variability and domestication in swine. J. Mamm., 61: 39-45.

20. Tamarin R. H. \& Krebs C. J., 1969: Microtus population biology. II. Genetic changes at the transferrin locus in fluctuating populations of two vole species. Evolution, 23: 183-211. 
21. Wright S., 1965: The interpretation of population structure by F-statistics with special regard to systems of mating. Evolution, 19: 395-420.

Accepted, June 22, 1980.

Anna FEDYK

\section{GENETYCZNE ZROŻICOWANIE WIOSENNEJ I JESIENNEJ GENERACJI NORNICY RUDEJ}

\section{Streszczenie}

U nornicy rudej łowionej w kwietniu-maju (generacja wiosenna) i wrześniupaździerniku (generacja jesienna) zbadano 17 różnych białek kodowanych przez 36 loci (wiosną 33 loci) (Tabela 1). Jesienna populacja składała się z osobników osiadłych i migrujących, wiosną łowiono tylko nornice osiadłe. Zatem między tymi trzema grupami nornic możliwe było porównanie frekwencji alleli (Tabela 2), indeksu genetycznego (Tabela 4) i średniej heterozygotyczności (Tabela 3). oraz dokonanie obliczeń podobieństwa genetycznego (Tabela 5). I tak średnia heterozygotyczność osobników osiadłych jesienią wynosi 0.032 a migrantów 0.035 , natomiast wiosną u osobników osiadłych równa się 0.042 . Współczynniki genetycznego podobieństwa dla migrantów i osiadłych wynoszą $0.970(I), 0.970(S)$; a przy porównaniu osobników osiadłych z wiosny i jesieni równe są 0.946 (I), 0.940 (S). Frekwencja alleli w niektórych ze zbadanych loci ulega dużym zmianom w poszczególnych grupach nornic a różnica jest największa między osiadlymi $\mathrm{z}$ wiosny i jesieni. Zatem można ogólnie stwierdzić, że uzyskane zróżnicowanie jest wyraźniej zaznaczone między sezonami niż między osiadłymi a migrantami z tego samego sezonu. 